\title{
New understandings of the genetic basis of isolated idiopathic central hypogonadism
}

\author{
Marco Bonomi ${ }^{1,2}$, Domenico Vladimiro Libri ${ }^{2,3}$, Fabiana Guizzardi $^{2}$, Elena Guarducci ${ }^{4}$, Elisabetta Maiolo ${ }^{5}$, \\ Elisa Pignatti ${ }^{6}$, Roberta Asci ${ }^{7}$, Luca Persani ${ }^{1,2,3}$ on behalf of the Idiopathic Central Hypogonadism Study Group of \\ the Italian Societies of Endocrinology and Pediatric Endocrinology and Diabetes*
}

\begin{abstract}
Idiopathic hypogonadotropic hypogonadism is a rare disease that is characterized by delayed/absent puberty and/or infertility due to an insufficient stimulation of an otherwise normal pituitary-gonadal axis by gonadotrophin-releasing hormone (GnRH) action. Because reduced or normal luteinizing hormone (LH)/follicle-stimulating hormone (FSH) levels may be observed in the affected patients, the term idiopathic central hypogonadism (ICH) appears to be more appropriate. This disease should be distinguished from central hypogonadism that is combined with other pituitary deficiencies. Isolated ICH has a complex pathogenesis and is fivefold more prevalent in males. ICH frequently appears in a sporadic form, but several familial cases have also been reported. This finding, in conjunction with the description of numerous pathogenetic gene variants and the generation of several knockout models, supports the existence of a strong genetic component. ICH may be associated with several morphogenetic abnormalities, which include osmic defects that, with ICH, constitute the cardinal manifestations of Kallmann syndrome (KS). KS accounts for approximately $40 \%$ of the total ICH cases and has been generally considered to be a distinct subgroup. However, the description of several pedigrees, which include relatives who are affected either with isolated osmic defects, $\mathrm{KS}$, or normo-osmic ICH (nICH), justifies the emerging idea that $\mathrm{ICH}$ is a complex genetic disease that is characterized by variable expressivity and penetrance. In this context, either multiple gene variants or environmental factors and epigenetic modifications may contribute to the variable disease manifestations. We review the genetic mechanisms that are presently known to be involved in $\mathrm{ICH}$ pathogenesis and provide a clinical overview of the $227 \mathrm{cases}$ that have been collected by the collaborating centres of the Italian ICH Network.
\end{abstract}

Asian Journal of Andrology (2012) 14,49-56; doi:10.1038/aja.2011.68; published online 5 December 2011

Keywords: central hypogonadism; congenital hypogonadism; GnRH; hypogonadotropic hypogonadism; hypothalamus-pituitarygonadal axis; Kallmann syndrome; male infertility

\section{INTRODUCTION}

The physiological function of the human hypothalamic-pituitarygonadal (HPG) axis is based on the pulsatile release of the hypothalamic gonadotrophin-releasing hormone $(\mathrm{GnRH})$, which is secreted into the hypophyseal portal circulation at the median eminence. The interaction of GnRH with its specific receptor (GnRH receptor (GnRHR)) on the pituitary gonadotropes stimulates the synthesis and secretion of the two pituitary gonadotrophins: luteinizing hormone ( $\mathrm{LH}$ ) and follicle-stimulating hormone (FSH). LH and FSH activate gonadal activity and gametogenesis in both sexes. $\mathrm{GnRH}$-secreting neurons arise in the olfactory placode of the human embryo and then migrate to their final destination in the mediobasal hypothalamus to terminate their differentiation and initiate the secretion of GnRH. ${ }^{1,2}$ This migration process is regulated by several factors, including the spatiotemporal expression patterns of axonal guidance cues, cell adhesion molecules, extracellular matrix proteins, and

${ }^{1}$ Division of Endocrinology and Metabolism, Istituto Auxologico Italiano IRCCS, 20149 Milan, Italy; ${ }^{2}$ Lab of Endocrine and Metabolic Research, Istituto Auxologico Italiano IRCCS, 20149 Milan, Italy; ${ }^{3}$ Department of Medical Sciences, University of Milan, 20122 Milan, Italy; ${ }^{4}$ Department of Clinical Pathophysiology, Unit of Andrology, University of Florence, 50134 Florence, Italy; ${ }^{5}$ Lab of Human and Medical Genetics, Ospedale Galliera, 16128 Genova, Italy; ${ }^{6}$ Department of Medicine, Endocrinology, Metabolism and Geriatrics, University of Modena and Reggio Emilia, 41126 Modena, Italy; ${ }^{7}$ CEINGE, University Federico II Naples and Dept. of Clinical and Experimental Medicine, Second University of Naples, 80131 Naples, Italy

Correspondence: Dr L Persani (luca.persani@unimi.it)

*The Idiopathic Central Hypogonadism Study Group of the Italian Societies of Endocrinology and Paediatric Endocrinology and Diabetes: Gianluca Aimaretti (Novara), Monica Altobelli (Bergamo), Giorgio Arnaldi (Ancona), Maurizia Baldi (Genoa), Luigi Bartalena (Varese), Luciano Beccaria (Lecco), Paolo Beck-Peccoz (Milan), Giuseppe Bellastella (Naples), Giorgio Borretta (Cuneo), Fabio Buzi (Brescia), Salvo Cannavò (Messina), Marco Cappa (Rome), Anna Cariboni (Milan), Tommaso Ciampani (Varese), Alessandro Cicognani (Bologna), Mariangela Cisternino (Pavia), Sabrina Corbetta (Milan), Nicola Corciulo (Lecce), Renato Cozzi (Milan), Angela Valentina D’Elia (Udine), Ettore Degli Uberti (Ferrara), Mario De Marchi (Turin), Gianni Forti (Florence), Natascia di lorgi (Genoa), Andrea Fabbri (Rome), Alberto Ferlin (Padua), Rossella Gaudino (Verona), Enrico Grosso (Turin), Csilla Krausz (Florence), Fabio Lanfranco (Turin), Daniela Larizza (Pavia), Paolo Limone (Turin), Mario Maggi (Florence), Roberto Maggi (Milan), Mohammad Maghnie (Genoa), Antonio Mancini (Rome), Giorgia Mandrile (Turin), Marco Marino (Modena), Maria Antonietta Mencarelli (Siena), Nicola Migone (Turin), Giovanni Neri (Rome), Lucia Perroni (Genova), Elisa Pignatti (Modena), Alba Pilotta (Brescia), Angela Ida Pincelli (Monza), Alessandro Pizzocaro (Milan), Alfredo Pontecorvi (Rome), Giorgio Radetti (Bolzano), Paola Razzore (Turin), Gianni Russo (Milan), Filippo Salvini (Milan), Andrea Secco (Genoa), Maria Segni (Rome), Manuela Simoni (Modena), Agostino Sinisi (Naples), Riccardo Vigneri (Catania), and Giovanna Weber (Milan).

Received: 1 July 2011; Revised: 6 September 2011; Accepted: 6 September 2011; Published online: 5 December 2011 
growth factors and neurotransmitters that determine the GnRH neuronal fate. ${ }^{3}$ The correct development and coordinated function of the GnRH-secreting neurons and the gonadotropes is essential for the correct activation of the gonads during foetal life and the neonatal period (the so-called 'minipuberty'). After a dormant phase during infancy and childhood, HPG activity is resumed at the time of the puberty and throughout the adult reproductive age.

Central hypogonadism $(\mathrm{CH})$ is either congenital or acquired, and it can be secondary to hypothalamic or pituitary lesions. $\mathrm{CH}$ may also be isolated or combined with other pituitary hormone defects. ${ }^{4}$ Here, we will focus on the isolated forms of $\mathrm{CH}$ that cause variable defects of pubertal development and infertility; these forms are generally classified as idiopathic central hypogonadism (ICH). ICH is a disease with a complex and still largely unknown pathogenesis that is caused by an insufficient stimulation of an otherwise normal pituitary-gonadal axis by $\mathrm{GnRH}$ action. In fact, ICH is biochemically characterized by low levels of sex steroids (testosterone or estradiol) in the presence of low/ normal levels of gonadotrophins ( $\mathrm{LH}$ and $\mathrm{FSH}$ ). In patients with normal levels of circulating gonadotrophins, LH and FSH are not secreted in a pulsatile manner and are therefore ineffective at the target level. ${ }^{5}$ $\mathrm{ICH}$ is a rare disease; its incidence is 1:8000 males and 1:40 000 females. It can be associated with either a normal or defective sense of smell, which identifies normo-osmic ICH (nICH) or Kallmann syndrome (KS), respectively. Males frequently present with defective androgenisation and growth at a peripubertal age, but micropenis and cryptorchidism may already be evident in the neonatal period, which indicates a defective activation of HPG during prenatal development. Females generally present with primary amenorrhea and growth retardation. Additional neurological (e.g., anosmia) and non-neurological (e.g., midline or kidney defects) defects may frequently coexist, and they can be linked to specific modes of inheritance. Indeed, KS was originally thought to be caused by mutations in a specific $\mathrm{X}$ chromosome gene, $K A L 1,{ }^{6-8}$ but this genetic defect was soon found to be present in only a minority of the patients. Nevertheless, the observation of familial cases with variable modes of ICH inheritance (X-linked or autosomal dominant or recessive) soon indicated that ICH retains a highly heterogeneous genetic component. The application of conventional linkage studies to investigate the genetic basis of ICH has proven to be difficult; most pedigrees tend to be small in size because the majority of patients remain infertile without treatment. ${ }^{9}$ In the past decade, however, key contributions (reviewed in Ref. 5) from animal and cellular models, and genetic studies in a series of patients have provided evidence of new genetic determinants of ICH (either $\mathrm{nICH}$ or KS). These advances have played a significant role in the elucidation of the pathophysiology of $\mathrm{ICH}$, and they have helped to discover the physiological complexities of the HPG axis.

\section{GENETICS OF ICH}

A multitude of candidate genes for ICH have been proposed, and a tentative schematic representation of the various mechanisms that can be disrupted by these genetic defects is reported in Figure 1. Some genes are required for the correct embryonic differentiation of the GnRH-secreting neurons, such as the receptor-ligand pair FGFR1/FGF8 (fibroblast growth factor receptor 1 and fibroblast growth factor 8), NELF (nasal embryonic LH-releasing hormone Factor) and HS6ST1 (heparan sulphate 6-O-sulphotransferase 1). Other genes encode the signals that are essential for the correct migration of the GnRH neurons from their embryonic origin to the hypothalamus, such as KAL1, the ligand-receptor complex PROK2/PROKR2 (prokineticin 2 and its receptor) and CHD7 (chromodomain helicase DNA-binding protein 7). Other genes encode the elements of upstream signals that contribute to the activation of the GnRH neuron, such as the two ligand-receptor complexes that are formed either by TAC3/TACR3 (tachykinin 3 and its receptor, which is also named neurokinin $B(N K B)$, and neurokinin 3 receptor (NK3)) or KISS1/KISS1R (kisspeptin 1 and its receptor, which was previously known as GPR54). Finally, candidate genes include the GnRH gene itself (GnRH1) and its receptor ( $G n R H R)$.

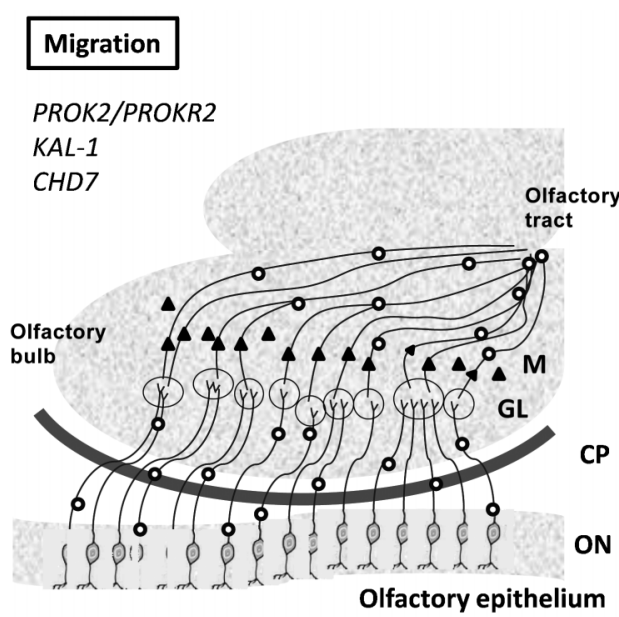

GnRH neuron genesis

FGF8/FGFR1

HS6ST1

NELF
Upstream signals

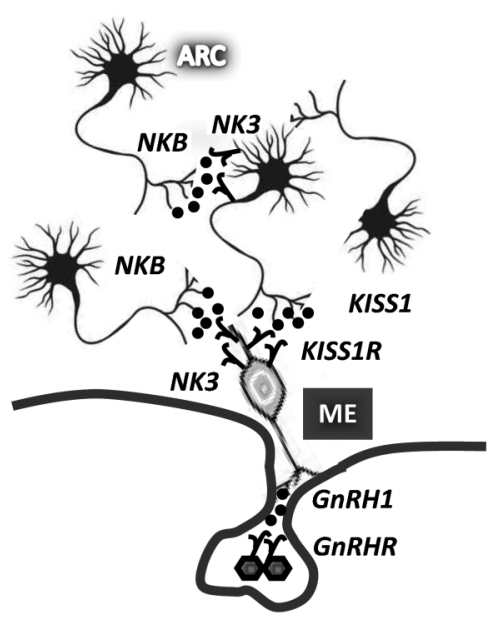

GnRH synthesis/action

Figure 1 Schematic representation of the genes implicated in HPG activation. In each step, the different genes whose genetic variants disrupt the HPG axis activity are indicated. ARC, arcuate nucleus; CP, cribriform plate; GL, glomerulus; HPG, hypothalamic-pituitary-gonadal; M, mitral cell; ME, median eminence; ON, olfactory neurons. 


\section{KAL1}

The KAL1 gene (OMIM number: 308700), which is located on chromosome Xp22.3, consists of 14 exons that encode an extracellular matrix glycoprotein of approximately $100 \mathrm{kDa}$ and is termed anosmin-1. It consists of a cysteine-rich region, a whey acidic protein domain and four fibronectin type III domains. ${ }^{6,7}$ The fibronectin type III domains appear to create a flat surface with a strong basic charge, which enables interactions to occur between anosmin-1 and other components of the extracellular matrix. ${ }^{10,11}$ Anosmin- 1 is expressed in the human forebrain at 5 weeks of gestation at the area of contact with the olfactory fibres and appears to stimulate afferent projections to the olfactory bulb. ${ }^{12}$ A post-mortem study of a 19-week-old male foetus with a deletion that included KAL1 provided important insights into the pathology of X-linked KS; this study revealed both an absence of olfactory bulbs and the abnormal migration of GnRH neurons that had differentiated from the olfactory placode and had begun to migrate before they were arrested in a tangle of olfactory neurons at the point of entry into the central nervous system. ${ }^{13}$ Various types of KAL1 gene abnormalities have been reported in patients with KS. These abnormalities include missense and nonsense mutations, splice site mutations, intragenic deletions and submicroscopic chromosomal deletions involving the entire KAL1 gene. ${ }^{14}$ Clinical features in mutation-positive males include ICH and anosmia/hyposmia. In addition, several non-reproductive and non-olfactory disorders are largely attributed to KAL1 defects, including midline facial defects, such as cleft lip and/or cleft palate, short metacarpals, renal agenesis, sensorineural hearing loss, bimanual synkinesia, oculomotor abnormalities and cerebellar ataxia. ${ }^{15}$ Of these defects, renal agenesis and bimanual synkinesis show the highest incidences; they occur in approximately 30\%-40\% and $75 \%$ of KS cases, respectively. ${ }^{16}$ KAL1 mutations have been detected in approximately $60 \%$ of patients with familial KS, which suggests an $\mathrm{X}$-linked mode of inheritance; they have been detected in only $10 \%$ $15 \%$ of male patients with sporadic KS. ${ }^{14}$ Furthermore, nearly all mutations have been identified in patients with both ICH and olfactory dysfunction of variable extents. To date, only one case with $\mathrm{nICH}$ and a KAL1 mutation has been reported in the literature. ${ }^{17}$

\section{FGFR1 and FGF8}

The FGFR1 gene (OMIM number: 136 350), which is also called KAL2, is located on chromosome $8 \mathrm{p} 12$ and comprises 18 exons. The mature FGFR1 protein belongs to the receptor tyrosine kinase superfamily, and it consists of four subtypes (FGFR1-4) and seven FGFR isoforms, which specifically bind to particular members of the 22 fibroblast growth factor (FGF) ligands. FGFR1 consists of three extracellular immunoglobulin-like loops (D1, D2 and D3), an acid box that is located between the first two immunoglobulin loops (the D1-D2 linker region that contains a stretch of negatively charged amino acids and a heparan sulphate-binding site within the first half of D2), a transmembrane domain and an intracellular split tyrosine kinase domain. ${ }^{18}$ Alternative splicing within the second half of the juxtamembrane D3 domain generates two transmembrane isoforms, IIIb and IIIc. ${ }^{19}$ The cognate FGF ligand binding is formed by the proximal membrane D2 and D3 domains. The D3 isoform determines ligand-binding specificity while the D1 domain can fold back to interact with D2 in the FGF and heparan sulphate (HS) contact sites; therefore, it functions as a potential competitive auto-inhibitor of the interaction between FGFR and FGF and HS. FGFR1 signalling is achieved by the induction of conformational changes in the receptor upon ligand binding, which leads to dimerisation and the subsequent activation by autophosphorylation of its intracellular tyrosine kinase domains. In addition to requiring two FGF ligands, the binding of heparin or HS proteoglycan is also essential for FGF receptor dimerisation and the activation of the FGF-FGFR complex. ${ }^{20}$ FGFR1 signalling has been shown to play a broad role during embryogenesis, homeostasis and wound healing. Several studies on the expression patterns of FGF ligands and receptors during central nervous system development have indicated the critical role of FGF in the initial generation of neural tissue. ${ }^{21}$ This activity is also present in the rostral forebrain; it directly affects the olfactory bulb development, which may influence the GnRH neuronal migratory activity. ${ }^{22} \mathrm{Fgfrl}^{-1-}$ knockout $(\mathrm{KO})$ mice show persistent cell proliferation within the anterior end of the telencephalon, and this leads aplasia in the olfactory bulbs. ${ }^{22}$ Furthermore, a $30 \%$ decrease in the number of hypothalamic GnRH neurons was observed in mice with dominant negative $\mathrm{FgfrI}^{-1-}$ mutations that were targeted to GnRH neurons, ${ }^{23}$ and the early emergence of $\mathrm{GnRH}$ neurons appeared to be disrupted in Fgfr $1^{-1-}$ hypomorphic mice. ${ }^{24}$ Therefore, loss-of-function mutations in FGFR1 result in a defect in GnRH neuron migration via the abnormal morphogenesis of the olfactory bulb, while specific gain-offunction mutations in FGFR1 cause craniosynostosis. ${ }^{25}$ Dode and Hardelin $^{16}$ first reported the association between FGFR1 loss-offunction mutations and the dominant form of KS. Since that observation, several FGFR1 mutations, all of which occurred in the FGFR1IIIC isoform and spanned all of the functional domains of the receptor, have been identified in KS-affected individuals and in patients with $\mathrm{nICH}^{26,27}$ Similar to KAL1 defects, other nonreproductive and non-olfactory disorders, such as cleft palate or lip, dental agenesis and bimanual synkinesis, are associated with KS due to FGFR1 defects. ${ }^{15}$ An important phenotypic variability has been reported in mutated FGFR1 in unrelated probands and mixed pedigrees. The coexistence of KS, isolated hyposmia without hypogonadism, and $\mathrm{nICH}$ was observed even in patients from the same family that shared an identical mutation. ${ }^{28}$ The presence of modifier genes, the involvement of multiple genes or an epigenetic mechanism may explain this different phenotypic expression of the same genetic defect. ${ }^{29}$ It is therefore evident that the precise quantitative regulation of FGFR1 signalling is essential for normal development, and both attenuated and increased signalling cause disparate phenotypes.

FGF family ligands consist of 22 structurally related proteins with primary sequence differences that determine the FGF-FGFR-specific interaction and thus regulate the diverse function of the FGF pathway. At least 11 different FGFs can activate FGFR1, but FGF8 has been identified as a key ligand for FGFRIIIIc in $\mathrm{KS}$ and $\mathrm{nICH}$ pathogenesis. $^{30}$ Thus, the FGF8 gene (OMIM number: 600483), which is located on chromosome 10q24, is also called KAL6. This role has been confirmed in mice that are homozygous for an Fgf8 hypomorphic allele; these mice had small telencephalons with no olfactory bulbs in addition to other cardiac, craniofacial, forebrain, midbrain and cerebellar developmental abnormalities, which included the absence of GnRH neurons. ${ }^{24,30}$ Overall, these data demonstrate the crucial role of FGF8-signalling activation through the assembly of the FGF8FGFR1-HS complex in the GnRH neuronal and olfactory system development. Nevertheless, other FGF mutations can impair the FGF-FGFR1 pathway and lead to ICH.

\section{HS6ST1}

During the preparation of this manuscript, HS6ST1, which is (OMIM number: 604846) located on chromosome 2q21 and involved in extracellular sugar modification, was indeed found to be mutated in patients with $\mathrm{ICH} .{ }^{31} \mathrm{HS}$ polysaccharides are extracellular matrix 
components that modulate the cell-cell communications that are important for neural development. ${ }^{32}$ This post-translational modification is important for the interaction and activation of the FGFRFGF complex ${ }^{20}$ and for the interaction of anosminl with the cell membrane. ${ }^{10,11,33}$ The importance of these molecular interactions has been confirmed in a model of transgenic nematodes that mis-/ overexpress the KAL1 orthologue in certain neurons; the axonbranching phenotype was reversed in mutant worms that lacked either HS6ST1 or C5-epimerase, which is another enzyme that is involved in the biosynthesis of HSPS chains. ${ }^{34,35}$ HS6ST1 appears to be mutated in $\mathrm{KS}$ or $\mathrm{nICH}$ patients with a wide spectrum of severity and timing of the onset of GnRH deficiency. ${ }^{31}$ Clinical variability is also evident both within and across families that carry the same genetic alteration. ${ }^{31}$ All of the identified HS6ST1 variants were also tested in vivo and in vitro, and they displayed impaired activities in both assays. ${ }^{31}$

\section{PROKR2 and PROK2}

Another pair of receptor-ligand genes, PROKR2 (OMIM number: 607123), which is located on chromosome 20p13 and also called KAL3, and PROK2 (OMIM number: 607002), which is located on chromosome 3p21.1 and also called KAL4, were considered to be potential causative genes of KS. The mutant mice that lacked PROKR2, which is a transmembrane receptor interacting with the heterotrimeric guanine nucleotide-binding proteins ( $\mathrm{G}$ proteincoupled receptor (GPCR)), presented abnormal olfactory bulb development that was combined with severe atrophy of the reproductive system. ${ }^{36}$ The prokineticin system is composed of two nearly identical (approximately $85 \%$ gene homology) receptors (PROKR1 and PROKR2) and their two polypeptide ligands, PROK1 and PROK2, which show considerably less homology and exhibit quite different anatomic distributions. Although PROK1 and its receptor, PROKR1, are primarily restricted to the gastrointestinal system where they are responsible for motility, $P R O K 2$ and $P R O K R 2$ have a more specific neuroendocrine profile; they are located in the arcuate nucleus, olfactory track and suprachiasmatic nucleus. ${ }^{37,38}$ In 2006, Dodé et al. ${ }^{39}$ demonstrated that mutations in these pairs of ligand-receptor genes cause human GnRH deficiency in patients with nICH or KS. Subsequently, many mutations were described in the literature; most of these mutations are missense mutations, and many are also present in apparently unaffected individuals, which raises questions regarding their pathogenic role in the disease. However, deleterious effects on prokineticin signalling have subsequently been shown in vitro for several variations. ${ }^{40,41}$ The finding of both heterozygous and homozygous (or compound heterozygous) unrelated patients with PROKR2 and PROK2 mutations ${ }^{39,42}$ is in favour of a possible oligogenic mode of inheritance in heterozygous patients, which has been demonstrated in some cases. ${ }^{29,42}$ A variety of accessory features, including fibrous dysplasia, sleep disorder, severe obesity, synkinesia and epilepsy, have been noted in patients with PROK2 or PROKR2 mutations. ${ }^{40}$

\section{KISS1R and KISS1}

The human GPR54 gene (OMIM number: 604161) is located on chromosome 19p13.3 and encodes a 398-amino acid GPCR whose ligand binding-induced activation determines, via a Gq pathway, the intracellular accumulation of IP3/calcium. ${ }^{43}$ GPR54 has been shown to be the receptor for small peptides that are derived from the KISS1 gene, ${ }^{44}$ which caused its recent redesignation as KISS1R. The KISS1 gene (OMIM number: 603286), which is located on chromosome 1q32, encodes a 145 -amino acid precursor peptide, kisspeptin 1, which produces four cleavage products: the longest 54-amino acid peptide, which is known as kisspeptin 54 or metastatin (composed of amino acids 68-121) and three smaller products of 14,13 and 10 residues (kisspeptin 14, kisspeptin 13 and kisspeptin 10). All four peptides exhibit the same affinity and efficacy towards KISS1R, indicating that the C-terminal end of the peptide is responsible for the binding and activation of the receptor. ${ }^{44,45}$ Although all four kisspeptin products are biologically active, ${ }^{46}$ the in vivo relevance of the shorter peptides is still unknown. KISS1R is expressed in both the hypothalamus and pituitary, while KISS1 is expressed only in the hypothalamus. ${ }^{44}$ Physiological and pharmacological studies have demonstrated the implication of the KISS1KISS1R complex in the HPG axis. Kiss $1 r^{-/-} \mathrm{KO}$ mice show an ICH phenotype with nearly absent sexual maturation even in the presence of eutopic GnRH-secreting neurons that have a normal GnRH content, which demonstrates that KISS1R affects either the processing or release of this hormone but not the migration of GnRH neurons. ${ }^{47,48}$ Several studies have demonstrated the ability of kisspeptin to elicit the release of $\mathrm{LH}$ and FSH in different animal species ${ }^{48-54}$ and in humans. ${ }^{55}$ This effect is mediated by the KISS1-KISS1R interaction because it is not present in the Kiss1r KO mice and is GnRH release-dependent; it is not directly due to kisspeptin action on the pituitary because it is inhibited by the co-administration of GnRH antagonist. ${ }^{49,50,56}$ Furthermore, multiple independent mouse knockouts of Kiss1r and Kiss1 have been described, and all of them recapitulate the human $\mathrm{nICH}$ phenotype, which confirms that KISS1/KISS1R are robust proximal regulators of GnRH release. ${ }^{57}$ KISS1-secreting neurons are also highly responsive to oestrogen, and they have been implicated in both the negative and positive central feedback of sex steroids to GnRH production. ${ }^{58-60}$ In 2003, using linkage mapping in familial $\mathrm{nICH}$, two different groups simultaneously discovered the presence of a loss-of-function mutation in KISSIR as genetic cause of nICH. ${ }^{47,61}$ Further reports of human loss-of-function mutations in KISS1R that were associated with autosomal recessive $\mathrm{nICH}$ have been published in recent years, although this genetic cause of $\mathrm{nICH}$ appears to be extremely rare. ${ }^{62}$ Considering the demonstrated importance of the KISS1-KISS1R complex in the control of pubertal onset, the KISS1 gene is another obvious candidate for genetic screening in cases of ICH. Nevertheless, no pathogenic KISS1 mutations in association with ICH have been reported to date.

\section{TACR3 and TAC3}

The application of the strategy of studying $\mathrm{nICH}$ in rare consanguineous families with multiple affected members and no mutations in known ICH-related genes led to the identification of three different loss-of-function mutations in TACR3 (OMIM number: 152332), which is the gene located on chromosome 4q25 that encodes NK3R, and one mutation in TAC3 (OMIM number: 162330), which is the gene that is located on chromosome $12 \mathrm{q} 13-\mathrm{q} 21$ and encodes NKB, which is the endogenous ligand of NK3R. ${ }^{63,64}$ Following these initial studies, defects in either TACR3 or TAC3 were found in several patients; this demonstrates that intact function of the $N K B / N K 3 R$ system is required for normal HPG activation at puberty. Moreover, the association of the TACR3 mutation with micropenis and cryptorchidism in male patients indicates that an intact $N K B / N K 3 R$ function is required for normal foetal gonadotrophin secretion. $N K B$ is a member of the tachykinin superfamily of neuropeptides that also includes substance $\mathrm{P}$ and neurokinin A. ${ }^{65}$ $N K 3 R$, which is a GPCR, is primarily expressed in the central 
nervous system and is the most selective one of the tachykinin receptors; it preferentially binds and is activated by $N K B .{ }^{66,67}$ The mechanism(s) by which mutations in the NKB pathway exert their effects on central neuroendocrine control of puberty and reproduction in humans is unclear. ${ }^{62} \mathrm{NKB}$ is expressed in the arcuate nucleus of hypothalamus neurons that project to GnRH secreting; here, kisspeptin is also expressed, and both peptides in the arcuate are downregulated by oestrogen. On the basis of these data, it is tempting to consider that kisspeptin and $N K B$ play similar roles in relaying feedback from sex steroids to GnRH production. However, other observations seem to indicate important differences in their actions, such as the different ability to stimulate $\mathrm{GnRH}$ release in different species (kisspeptin can stimulate this release in almost all species, but $N K B$ cannot), or the different phenotypes that have been observed in $\mathrm{KO}$ mice models of kisspeptin or NKB resistance, which are associated with a classic ICH phenotype ${ }^{67}$ or grossly normal fertility, ${ }^{68}$ respectively. $N K B$ has a wider pattern of central nervous system expression than KISS $1,{ }^{69}$ which suggests that the arcuate may not be the sole, or even the most important, site at which $N K B$ exerts its influence on reproductive function. Moreover, the investigations in mutation-carrying patients at several developmental windows demonstrated that variants in the NKB pathway can profoundly impact the function of the HPG axis in late gestation; however, the effect of these same mutations appears to become attenuated over time with the partial or complete reversal of hypogonadotropism in adult life.

\section{GnRHR and GnRH}

While the most obvious autosomal candidate gene for GnRH deficiency is the GnRH gene itself (OMIM number: 152760), which is located on 8 p21-8p11.2, it was only in 2009 that the first genetic defects in the GNRH1 gene were reported..$^{70,71} \mathrm{GnRH}$, which acts via the GnRH receptor, is one of the most important factors within the HPG axis, and it has long been the most obvious candidate gene to produce a purely functional defect in its activity. This is in accordance with the phenotype that is apparent in the hypogonadal $(h p g)$ mouse experimental model, in which $\mathrm{CH}$ is linked to an autosomal recessive mutation in the GnRH gene and results in the complete absence of GnRH synthesis. ${ }^{72,73} \mathrm{Hpg}$ mice are sexually infantile, infertile and present a hormone profile that is characterized by low sex steroid and gonadotrophin levels. ${ }^{73}$ In addition to their reproductive deficits, these mice present a phenotype that is grossly normal with the exception of abnormal tooth maturation and biomineralisation. ${ }^{74}$ Moreover, the reproductive deficits of the $h p g$ mice were completely reversed and the GnRH expression was restored by gene therapy. ${ }^{72}$ The second factor in this receptor-ligand pair is GnRHR, in which genetic defects began to be described 15 years ago in ICH patients. ${ }^{75}$ The GnRHR gene (OMIM number: 138850), which is located on chromosome $4 \mathrm{q} 21.2$, encodes a seven transmembrane-spanning GPCR. The activation of GnRHR results in the increased activity of phospholipase $\mathrm{C}$ and the mobilisation of intracellular calcium by means of the Gq/G11 group of G proteins. Null Gnrhr mice models display a similar phenotype to clinical ICH syndrome. A more severe phenotype was observed in the gene trap Gnrhr-null mouse model ${ }^{76}$ compared with the $N$-ethyl- $N$-nitrosourea-induced model, ${ }^{77}$ and they display small sexual organs with low LH/FSH and sex steroid levels, the failure of sexual maturation, infertility and the inability to respond to exogenous GnRH. Following the initial report in humans, several additional GnRHR mutations have been described, including mutations in the transmembrane domains, which significantly impair GnRH binding and/or signalling. ${ }^{15}$ These variable genotypes result in a wide phenotypic spectrum that ranges from fertile eunuch syndrome and partial idiopathic hypogonadotropic hypogonadism to the most complete form of GnRH resistance that is characterized by cryptorchidism, micropenis, undetectable gonadotrophins and the absence of pubertal development. ${ }^{78}$ Nevertheless, both GnRH1 and GnRHR defects produce classic isolated $\mathrm{nICH}$ without any associated developmental defects. $^{62}$

\section{CHD7}

CHARGE syndrome (colobomata, heart anomalies, choanal atresia, retardation, genital and ear anomalies) is a multisystem autosomal dominant syndrome that shares overlapping features of ICH and hyposmia with KS. CHARGE syndrome is caused by a mutation in the CHD7 gene (chromodomain helicase DNA-binding protein 7; OMIM number: 608892), which is located on chromosome 8q12.1. A CHD7 genetic screen in a series of ICH/KS patients demonstrated a mutational prevalence of $6 \%$, which therefore suggested that KS/ ICH were mild allelic variants of CHARGE syndrome and might be caused by $C H D 7$ gene mutations; ${ }^{79}$ CHD7 is also known as KAL5. Further studies have demonstrated that $\mathrm{CHD} 7$ mutations may be present in KS patients who had additional features of the CHARGE syndrome phenotype. ${ }^{80}$ Thus, CHD7 genetic screening may be considered for KS/ICH patients who present special features, such as deafness, dysmorphic ears and/or hypoplasia or aplasia of the semicircular canals.

\section{NELF}

The Nelf (nasal embryonic LH-releasing hormone factor) protein was first isolated in mouse, and the expression patterns of the Nelfgene in the olfactory axons and GnRH-secreting neurons during development are consistent with its function as a migratory factor for GnRH neurons. ${ }^{81,82}$ However, although rare sequence variants have been reported in KS patients, ${ }^{29,83-85}$ no functional studies have been reported thus far.

\section{EBF2}

The Ebf2 gene plays a key role in the neuroendocrine axis as proposed by Corradi et al. ${ }^{86}$ In Ebf2-null mutants, because of the defective migration of gonadotrophin-releasing, hormone-synthesising neurons, the formation of the neuroendocrine axis is impaired; this leads to secondary hypogonadism. To date, no mutations have been reported in the human series of $\mathrm{KS} / \mathrm{nICH}^{87}$

\section{CRITICAL ASPECTS OF ICH PHENOMICS AND GENOMICS}

ICH has been classically classified into two distinct clinical entities, KS and $\mathrm{nICH}$. However, such separate classification has been questioned in recent years, because these two entities may exist in different relatives within unique familial settings, which therefore supports the idea that they may constitute different phenotypic manifestations of the same genetic defect. ${ }^{26,28,75,88-90}$ On the basis of this possibility, a novel idea is that ICH may be considered to be a complex genetic disease that is characterized by variable expressivity, penetrance and modes of inheritance. As in multifactorial complex diseases, the pathogenesis of ICH may include the influence of environmental factors, which may exert epigenetic effects on gene expression, and the concurrent involvement of single nucleotide polymorfisms or other genetic defects in two or multiple interacting genes. Indeed, recent reports of patients who harbour pathogenic rare variants in more than one gene have challenged the long-held view of a strictly monogenic 
Table 1 Primary clinical features of the Italian ICH series

\begin{tabular}{llll}
\hline & KS & $n / C H$ & Total \\
\hline Groups ( $n$ and sex distribution \%) & $97(43 \%)$ (1 male; 6 females) & $130(57 \%)$ (1 male; 4 females) & 227 (male: 83\%; female: 17\%) \\
Age at diagnosis (years, range) & $2-45$ & $13-61$ & - \\
Familial cases & $20 / 97(20.0 \%)$ & $17 / 130(13.0 \%)$ & $37 / 227(16.2 \%)$ \\
Midline defects & $12 / 97(12.3 \%)$ & $3 / 130(2.3 \%)$ & $15 / 227(6.6 \%)$ \\
Bimanual synkinesis & $4 / 97(4.1 \%)$ & $0 / 130$ & $4 / 227(1.7 \%)$ \\
Renal agenesia/aplasia & $3 / 97(3.1 \%)$ & $1 / 130(0.7 \%)$ & $4 / 227(1.7 \%)$ \\
Hearing defects & $2 / 97(2.1 \%)$ & $0 / 130$ & $2 / 227(0.8 \%)$ \\
Cryptorchidism & $29 / 83(35.0 \%)$ (monolateral: 14; bilateral: 15) & $11 / 105(10.0 \%)$ (monolateral: 3; bilateral: 9) & $40 / 188(21.2 \%)($ monolateral: 17; bilateral: 24)
\end{tabular}

Abbreviations: ICH, idiopathic central hypogonadism; KS, Kallmann syndrome; nICH, normo-osmic ICH.

disorder. Oligogenicity, which is as frequent as the biallelic defects in a single gene, may partially account for the phenotypic variability of isolated GnRH deficiency. ${ }^{29}$ Furthermore, the gene-environment interaction is supported by: (i) the presence of rare variants in genes for isolated GnRH deficiency in unaffected patients, which suggests that such variants may also underlie milder forms of GnRH deficiency when combined with environmental factors, which was recently described in a series of patients with acquired hypothalamic amenorrhea and heterozygous rare variants in FGFR1, KAL1, PROKR2 and GnRHR; ${ }^{91}$ (ii) the occasional adult onset of ICH following normal puberty and reproductive function; ${ }^{92,93}$ and (iii) the reversal of $\mathrm{ICH}$ in a subset of patients who experience an extremely delayed onset of a spontaneous GnRH function during the withdrawal of steroid administration, which can even occur beyond 25 years of age. ${ }^{94}$

\section{THE ITALIAN NETWORK FOR ICH}

Because of the involvement of numerous clinicians from several Italian regions (see the list at the note of first page of the manuscript) and thanks to the support of the Italian Societies of Endocrinology and Paediatric Endocrinology and Diabetes, we were able to collect a large series of patients who are affected with ICH. To date, we have collected a total number of $227 \mathrm{ICH}$ patients, which are $83 \%$ males and $17 \%$ females and have either KS (43\%; 1 female: 6 males) or nICH (57\%; 1 female: 4 males). The most important clinical data are summarized in Table 1.

Because genetic investigations that are aimed to reveal the possible genetic cause of ICH in a single case are extremely expensive and tedious and cannot be sustained by a single centre, we decided to coordinate the efforts of several molecular biology laboratories in Italy to set up an extensive service of genetic analyses that are aimed to support counselling of families at risk. Therefore, because of the contribution of the collaborating Italian centres, we began to screen the entire coding regions of the most relevant candidate genes for $\mathrm{ICH}$ pathogenesis. The current results are summarized in Table 2 , and they show the identification of a contributing genetic defect in approximately $35 \%$ of the patients. Genetic data from Italian patients show a major involvement of KAL1, FGFR1 and PROKR2, and the rare involvement of variants in the other candidate genes. Compared with the data that have been reported in the literature, our series seem to show a higher percentage of genetic alterations in the FGFR1 and PROKR2 genes and a lower percentage in the GnRHR gene in the nICH patients (see data in Table 2 and in Ref. 62). Of note, we have not yet identified any alterations in the coding regions of GNRH1, KISS1R, TAC3 and TACR3, although the screening of these genes was so far accomplished in only a part of the entire cohort. Interestingly, in our series, a digenic involvement was detected in three cases. Overall, these data indicate that we can support genetic counselling for approximately one-third of the affected families. Such an outcome may be considered to be valuable because it can lead to the early recognition and prepubertal treatment of several ICH cases. Nevertheless, the genetic studies were negative in approximately $65 \%$ of the patients, which is similar to the results that have been reported in the literature.

\section{FUTURE PERSPECTIVES}

Because two-thirds of ICH patients lack a clear molecular basis, new strategic and methodological advances are needed to cover this gap. The likely involvement of still-unknown candidate genes may be identified by the use of exome sequencing or genome-wide investigation techniques. Moreover, the contributions of cryptic genetic defects that are unresolved by direct sequencing or those of alterations in nongenetic mechanisms that regulate gene expression (i.e., abnormal states of gene methylation or micro-RNA defects) still remain to be elucidated. Nevertheless, the accumulation of large consortia is required to cover the elevated costs and collect sufficiently numerous cohorts to increase the success rate of these experiments that investigate the whole genome or the regulatory mechanisms without any prior selection.

\section{COMPETING FINANCIAL INTERESTS}

The authors declare no conflict of interest related to this work.

\section{ACKNOWLEDGMENTS}

The financial support of funds for Young Investigators from the Italian Ministry of Health (Grant No. GR2008-1137632) and IRCCS Istituto

Table 2 Results of the analyses of the principal candidate genes in the Italian ICH series

\begin{tabular}{|c|c|c|c|c|c|c|c|c|c|c|c|}
\hline & Fgfr 1 & Fgf8 & Prok2 & ProkR2 & Kall & GnRHR & $G n R H 1$ & KissR1 & Tac3 & TacR3 & Ebf2 \\
\hline KS & $8 / 77$ & $1 / 23$ & 2/95 & $10 / 95$ & $6 / 64$ & $0 / 43$ & $0 / 37$ & $0 / 40$ & $0 / 5$ & $0 / 5$ & $0 / 21$ \\
\hline $\mathrm{nICH}$ & 9/110 & $2 / 57$ & $2 / 129$ & $7 / 129$ & - & $4 / 58$ & $0 / 56$ & $0 / 53$ & $0 / 13$ & $0 / 13$ & - \\
\hline Total & $\begin{array}{l}17 / 187 \\
(9 \%)\end{array}$ & $\begin{array}{l}3 / 80 \\
(3.7 \%)\end{array}$ & $\begin{array}{l}4 / 224 \\
(1.7 \%)\end{array}$ & $\begin{array}{l}17 / 224 \\
(7.5 \%)\end{array}$ & $\begin{array}{l}6 / 64 \\
(9.3 \%)\end{array}$ & $\begin{array}{l}4 / 101 \\
(3.9 \%)\end{array}$ & $0 / 93$ & 0/93 & $0 / 18$ & $0 / 18$ & $0 / 21$ \\
\hline
\end{tabular}

Abbreviations: ICH, idiopathic central hypogonadism; KS, Kallmann syndrome; nICH, normo-osmic ICH. 
Auxologico Italiano (Ricerca Corrente Funds: 05C701) is gratefully acknowledged.

1 Schwanzel-Fukuda M, Pfaff DW. Origin of luteinizing hormone-releasing hormone neurons. Nature 1989; 338: 161-4.

2 Wray S, Grant P, Gainer H. Evidence that cells expressing luteinizing hormonereleasing hormone mRNA in the mouse are derived from progenitor cells in the olfactory placode. Proc Natl Acad Sci USA 1989; 86: 8132-6.

3 Gonzalez-Martinez D, Hu Y, Bouloux PM. Ontogeny of GnRH and olfactory neuronal systems in man: novel insights from the investigation of inherited forms of Kallmann's syndrome. Front Neuroendocrinol 2004; 25: 108-30.

4 Cadman SM, Kim SH, Hu Y, Gonzalez-Martinez D, Bouloux PM. Molecular pathogenesis of Kallmann's syndrome. Horm Res 2007; 67: 231-42.

5 Mitchell AL, Dwyer A, Pitteloud N, Quinton R. Genetic basis and variable phenotypic expression of Kallmann syndrome: towards a unifying theory. Trends Endocrino Metab 2011; 22: 249-58.

6 Franco B, Guioli S, Pragliola A, Incerti B, Bardoni B et al. A gene deleted in Kallmann's syndrome shares homology with neural cell adhesion and axonal path-finding molecules. Nature 1991; 353: 529-36.

7 Legouis R, Hardelin JP, Levilliers J, Claverie JM, Compain S et al. The candidate gene for the $\mathrm{X}$-linked Kallmann syndrome encodes a protein related to adhesion molecules. Cell 1991; 67: 423-35.

8 Hardelin JP, Levilliers J, del Castillo I, Cohen-Salmon M, Legouis R et al. $\mathrm{X}$ chromosome-linked Kallmann syndrome: stop mutations validate the candidate gene. Proc Natl Acad Sci USA 1992; 89: 8190-4.

9 Quinton R, Duke VM, Robertson A, Kirk JM, Matfin G et al. Idiopathic gonadotrophin deficiency: genetic questions addressed through phenotypic characterization. Clin Endocrinol (Oxf) 2001; 55: 163-74.

10 Hu Y, Gonzalez-Martinez D, Kim SH, Bouloux PM. Cross-talk of anosmin-1, the protein implicated in X-linked Kallmann's syndrome, with heparan sulphate and urokinasetype plasminogen activator. Biochem J 2004; 384: 495-505.

11 Soussi-Yanicostas N, Hardelin JP, Arroyo-Jimenez MM, Ardouin O, Legouis R et al. Initial characterization of anosmin-1, a putative extracellular matrix protein synthesized by definite neuronal cell populations in the central nervous system. J Cell Sci 1996; 109(Pt 7): 1749-57.

12 Hardelin JP, Julliard AK, Moniot B, Soussi-Yanicostas N, Verney C et al. Anosmin-1 is a regionally restricted component of basement membranes and interstitia matrices during organogenesis: implications for the developmental anomalies of X chromosome-linked Kallmann syndrome. Dev Dyn 1999; 215: 26-44.

13 Schwanzel-Fukuda M, Bick D, Pfaff DW. Luteinizing hormone-releasing hormone (LHRH)-expressing cells do not migrate normally in an inherited hypogonadal (Kallmann) syndrome. Brain Res Mol Brain Res 1989; 6: 311-26.

14 Bianco SD, Kaiser UB. The genetic and molecular basis of idiopathic hypogonadotropic hypogonadism. Nat Rev Endocrinol 2009; 5: 569-76.

15 Trarbach EB, Silveira LG, Latronico AC. Genetic insights into human isolated gonadotropin deficiency. Pituitary 2007; 10: 381-91.

16 Dode C, Hardelin JP. Kallmann syndrome: fibroblast growth factor signaling insufficiency? J Mol Med 2004; 82: 725-34.

17 Sato N, Katsumata N, Kagami M, Hasegawa T, Hori N et al. Clinical assessment and mutation analysis of Kallmann syndrome 1 (KAL1) and fibroblast growth facto receptor 1 (FGFR1, or KAL2) in five families and 18 sporadic patients. J Clin Endocrinol Metab 2004; 89: 1079-88.

18 Groth C, Lardelli M. The structure and function of vertebrate fibroblast growth factor receptor 1. Int J Dev Biol 2002; 46: 393-400.

19 Mohammadi M, Olsen SK, Ibrahimi OA. Structural basis for fibroblast growth factor receptor activation. Cytokine Growth Factor Rev 2005; 16: 107-37.

20 Ibrahimi OA, Zhang F, Hrstka SC, Mohammadi M, Linhardt RJ. Kinetic model for FGF, FGFR, and proteoglycan signal transduction complex assembly. Biochemistry 2004, 43: 4724-30

21 González-Martínez D, Kim SH, Hu Y, Guimond S, Schofield J et al. Anosmin-1 modulates fibroblast growth factor receptor 1 signaling in human gonadotropinreleasing hormone olfactory neuroblasts through a heparan sulfate-dependent mechanism. J Neurosci 2004; 24: 10384-92.

22 Hebert JM, Lin M, Partanen J, Rossant J, McConnell SK. FGF signaling through FGFR is required for olfactory bulb morphogenesis. Development 2003; 130: 1101-11.

23 Tsai PS, Moenter SM, Postigo HR, el Majdoubi M, Pak TR et al. Targeted expression of a dominant-negative fibroblast growth factor (FGF) receptor in gonadotropin-releasing hormone $(\mathrm{GnRH})$ neurons reduces FGF responsiveness and the size of $\mathrm{GnRH}$ neuronal population. Mol Endocrinol 2005; 19: 225-36.

24 Chung WC, Moyle SS, Tsai PS. Fibroblast growth factor 8 signaling through fibroblast growth factor receptor 1 is required for the emergence of gonadotropin-releasing hormone neurons. Endocrinology 2008; 149: 4997-5003.

$25 \mathrm{Hu}$ Y, Bouloux PM. Novel insights in FGFR1 regulation: lessons from Kallmann syndrome. Trends Endocrinol Metab 2010; 21: 385-93.

26 Pitteloud N, Acierno JS Jr, Meysing A, Eliseenkova AV, Ma J et al. Mutations in fibroblast growth factor receptor 1 cause both Kallmann syndrome and normosmic idiopathic hypogonadotropic hypogonadism. Proc Natl Acad Sci USA 2006; 103 6281-6.

27 Trarbach EB, Costa EM, Versiani B, de Castro M, Baptista MT et al. Novel fibroblast growth factor receptor 1 mutations in patients with congenital hypogonadotropic hypogonadism with and without anosmia. J Clin Endocrinol Metab 2006; 91 4006-12.

28 Pitteloud N, Meysing A, Quinton R, Acierno JS Jr, Dwyer AA et al. Mutations in fibroblast growth factor receptor 1 cause Kallmann syndrome with a wide spectrum of reproductive phenotypes. Mol Cell Endocrinol 2006; 254-255: 60-9.

29 Sykiotis GP, Plummer L, Hughes VA, Au M, Durrani S et al. Oligogenic basis of isolated gonadotropin-releasing hormone deficiency. Proc Natl Acad Sci USA 2010; 107 15140-4.

30 Falardeau J, Chung WC, Beenken A, Raivio T, Plummer L et al. Decreased FGF8 signaling causes deficiency of gonadotropin-releasing hormone in humans and mice J Clin Invest 2008: 118: 2822-31.

31 Tornberg J, Sykiotis GP, Keefe K, Plummer L, Hoang X et al. Heparan sulfate 6-O sulfotransferase 1 , a gene involved in extracellular sugar modifications, is mutated in patients with idiopathic hypogonadotrophic hypogonadism. Proc Natl Acad Sci USA 2011; 108: 11524-9.

32 Inatani M, Irie F, Plump AS, Tessier-Lavigne M, Yamaguchi Y. Mammalian brain morphogenesis and midline axon guidance require heparan sulfate. Science 2003, 302: 1044-6.

33 Hudson ML, Kinnunen T, Cinar HN, Chisholm AD. C. elegans Kallmann syndrome protein KAL-1 interacts with syndecan and glypican to regulate neuronal cell migrations. Dev Biol 2006; 294: 352-65.

34 Bulow HE, Berry KL, Topper LH, Peles E, Hobert O. Heparan sulfate proteoglycandependent induction of axon branching and axon misrouting by the Kallmann syndrome gene kal-1. Proc Natl Acad Sci USA 2002; 99: 6346-51.

35 Bulow HE, Hobert O. Differential sulfations and epimerization define heparan sulfate specificity in nervous system development. Neuron 2004; 41: 723-36.

36 Matsumoto S, Yamazaki C, Masumoto KH, Nagano M, Naito M et al. Abnormal development of the olfactory bulb and reproductive system in mice lacking prokineticin receptor PKR2. Proc Natl Acad Sci USA 2006; 103: 4140-5.

37 Li M, Bullock CM, Knauer DJ, Ehlert FJ, Zhou QY. Identification of two prokineticin cDNAs: recombinant proteins potently contract gastrointestinal smooth muscle. $\mathrm{Mol}$ Pharmacol 2001; 59: 692-8.

38 Masuda Y, Takatsu Y, Terao Y, Kumano S, Ishibashi Y et al. Isolation and identification of EG-VEGF/prokineticins as cognate ligands for two orphan G-protein-coupled receptors. Biochem Biophys Res Commun 2002; 293: 396-402.

39 Dodé C, Teixeira L, Levilliers J, Fouveaut C, Bouchard P et al. Kallmann syndrome: mutations in the genes encoding prokineticin-2 and prokineticin receptor-2. PLoS Genet 2006; 2: e175.

40 Cole LW, Sidis Y, Zhang C, Quinton R, Plummer L et al. Mutations in prokineticin 2 and prokineticin receptor 2 genes in human gonadotrophin-releasing hormone deficiency: molecular genetics and clinical spectrum. J Clin Endocrinol Metab 2008; 93: 3551-9.

41 Monnier C, Dodé C, Fabre L, Teixeira L, Labesse G et al. PROKR2 missense mutations associated with Kallmann syndrome impair receptor signalling activity. Hum $\mathrm{Mol}$ Genet 2009; 18: 75-81.

42 Leroy C, Fouveaut C, Leclercq S, Jacquemont S, Boullay HD et al. Biallelic mutations in the prokineticin-2 gene in two sporadic cases of Kallmann syndrome. Eur J Hum Genet 2008; 16: 865-8.

43 Leroy C, Fouveaut C, Leclercq S, Jacquemont S, Boullay HD et al. Discovery of a receptor related to the galanin receptors. FEBS Lett 1999; 446: 103-7.

44 Kotani M, Detheux M, Vandenbogaerde A, Communi D, Vanderwinden JM et al. The metastasis suppressor gene KiSS-1 encodes kisspeptins, the natural ligands of the orphan G protein-coupled receptor GPR54. J Biol Chem 2001; 276: 34631-6.

45 Kotani M, Detheux M, Vandenbogaerde A, Communi D, Vanderwinden JM et al. Metastasis suppressor gene KiSS-1 encodes peptide ligand of a G-protein-coupled receptor. Nature 2001; 411: 613-7.

46 Kotani M, Detheux M, Vandenbogaerde A, Communi D, Vanderwinden JM et al AXOR12, a novel human G protein-coupled receptor, activated by the peptide KiSS1. J Biol Chem 2001; 276: 28969-75.

47 Seminara SB, Messager S, Chatzidaki EE, Thresher RR, Acierno JS Jr et al. The GPR54 gene as a regulator of puberty. N Engl J Med 2003; 349: 1614-27.

48 Messager S, Chatzidaki EE, Ma D, Hendrick AG, Zahn D. Kisspeptin directly stimulates gonadotropin-releasing hormone release via $\mathrm{G}$ protein-coupled receptor 54. Proc Natl Acad Sci USA 2005; 102: 1761-6.

49 Gottsch ML, Cunningham MJ, Smith JT, Popa SM, Acohido BV et al. A role for kisspeptins in the regulation of gonadotropin secretion in the mouse. Endocrinology 2004; 145: 4073-7

50 Matsui $\mathrm{H}$, Takatsu Y, Kumano S, Matsumoto H, Ohtaki T. Peripheral administration of metastin induces marked gonadotropin release and ovulation in the rat. Biochem Biophys Res Commun 2004; 320: 383-8.

51 Irwig MS, Fraley GS, Smith JT, Acohido BV, Popa SM et al. Kisspeptin activation of gonadotropin releasing hormone neurons and regulation of KiSS-1 mRNA in the male rat. Neuroendocrinology 2004; 80: 264-72.

52 Shahab M, Mastronardi C, Seminara SB, Crowley WF, Ojeda SR et al. Increased hypothalamic GPR54 signaling: a potential mechanism for initiation of puberty in primates. Proc Natl Acad Sci USA 2005; 102: 2129-34

53 Plant TM, Ramaswamy S, DiPietro MJ. Repetitive activation of hypothalamic G protein-coupled receptor 54 with intravenous pulses of kisspeptin in the juvenile monkey (Macaca mulatta) elicits a sustained train of gonadotropin-releasing hormone discharges. Endocrinology 2006; 147: 1007-13.

54 Navarro VM, Castellano JM, Fernández-Fernández R, Barreiro ML, Roa J, Navarro VM et al. Developmental and hormonally regulated messenger ribonucleic acid expression of KiSS-1 and its putative receptor, GPR54, in rat hypothalamus and poten 
Idiopathic central hypogonadism

M Bonomi et al

56

luteinizing hormone-releasing activity of KiSS-1 peptide. Endocrinology 2004; 145 : 4565-74.

55 Dhillo WS, Chaudhri OB, Patterson M, Thompson EL, Murphy KG et al. Kisspeptin-54 stimulates the hypothalamic-pituitary gonadal axis in human males. J Clin Endocrinol Metab 2005; 90: 6609-15.

56 Navarro VM, Castellano JM, Fernández-Fernández R, Tovar S, Roa J et al. Characterization of the potent luteinizing hormone-releasing activity of KiSS-1 peptide, the natural ligand of GPR54. Endocrinology 2005; 146: 156-63.

57 Chan YM, Broder-Fingert S, Seminara SB. Reproductive functions of kisspeptin and Gpr54 across the life cycle of mice and men. Peptides 2009; 30: 42-8.

58 Rance NE. Menopause and the human hypothalamus: evidence for the role of kisspeptin/neurokinin $B$ neurons in the regulation of estrogen negative feedback. Peptides 2009; 320: 111-22.

59 Clarkson J, d'Anglemont de Tassigny X, Colledge WH, Caraty A, Herbison $A E$. Distribution of kisspeptin neurones in the adult female mouse brain. J Neuroendocrinol 2009; 21: 673-82.

60 Clarkson J, Herbison AE. Oestrogen, kisspeptin, GPR54 and the pre-ovulatory luteinising hormone surge. J Neuroendocrinol 2009; 21: 305-11.

61 de Roux N, Genin E, Carel JC, Matsuda F, Chaussain JL et al. Hypogonadotropic hypogonadism due to loss of function of the KiSS1-derived peptide receptor GPR54. Proc Natl Acad Sci USA 2003; 100: 10972-6.

62 Semple RK, Topaloglu AK. The recent genetics of hypogonadotrophic hypogonadism-novel insights and new questions. Clin Endocrinol (Oxf) 2010; 72: 427-35.

63 Topaloglu AK, Reimann F, Guclu M, Yalin AS, Kotan LD et al. TAC3 and TACR3 mutations in familial hypogonadotropic hypogonadism reveal a key role for Neurokinin B in the central control of reproduction. Nat Genet 2009; 41: 354-8.

64 Guran T, Tolhurst G, Bereket A, Rocha N, Porter KT et al. Hypogonadotropic hypogonadism due to a novel missense mutation in the first extracellular loop of the neurokinin B receptor. J Clin Endocrinol Metab 2009; 94: 3633-9.

65 Guran T, Tolhurst G, Bereket A, Rocha N, Porter K et al. mRNA expression of tachykinins and tachykinin receptors in different human tissues. Eur J Pharmacol 2004; 494: 233-9.

66 Maggi CA, Schwartz TW. The dual nature of the tachykinin NK1 receptor. Trends Pharmacol Sci 1997; 18: 351-55.

67 Sandoval-Guzman T, Rance NE. Central injection of senktide, an NK3 receptor agonist, or neuropeptide $Y$ inhibits LH secretion and induces different patterns of Fos expression in the rat hypothalamus. Brain Res 2004; 1026: 307-12.

68 Kung TT, Crawley Y, Jones H, Luo B, Gilchrest H et al. Tachykinin NK3-receptor deficiency does not inhibit pulmonary eosinophilia in allergic mice. Pharmacol Res 2004; 50: 611-5.

69 Chawla MK, Gutierrez GM, Young WS3rd, McMullen NT, Rance NE. Localization of neurons expressing substance $P$ and neurokinin $B$ gene transcripts in the human hypothalamus and basal forebrain. J Comp Neurol 1997; 384: 429-42.

70 Bouligand J, Ghervan C, Tello JA, Brailly-Tabard S, Salenave S et al. Isolated familial hypogonadotropic hypogonadism and a GNRH1 mutation. N Engl J Med 2009; 360: 2742-8.

71 Chan YM, de Guillebon A, Lang-Muritano M, Plummer L, Cerrato F et al. GNRH1 mutations in patients with idiopathic hypogonadotropic hypogonadism. Proc NatI Acad Sci USA 2009; 106: 11703-8.

72 Mason AJ, Pitts SL, Nikolics K, Szonyi E, Wilcox JN et al. The hypogonadal mouse: reproductive functions restored by gene therapy. Science $1986 ; 234$ : 1372-8.

73 Cattanach BM, Iddon CA, Charlton HM, Chiappa SA, Fink G. Gonadotrophin-releasing hormone deficiency in a mutant mouse with hypogonadism. Nature 1977; 269: 338-40.

74 Tiong J, Locastro T, Wray S. Gonadotropin-releasing hormone-1 (GnRH-1) is involved in tooth maturation and biomineralization. Dev Dyn 2007; 236: 2980-92.
75 de Roux N, Young J, Misrahi M, Genet R, Chanson P et al. A family with hypogonadotropic hypogonadism and mutations in the gonadotropin-releasing hormone receptor. N Engl J Med 1997; 337: 1597-602.

76 Wu S, Wilson MD, Busby ER, Isaac ER, Sherwood NM et al. Disruption of the single copy gonadotropin-releasing hormone receptor in mice by gene trap: severe reduction of reproductive organs and functions in developing and adult mice. Endocrinology 2010; 151: 1142-52.

77 Pask AJ, Kanasaki H, Kaiser UB, Conn PM, Janovick JA et al. A novel mouse model of hypogonadotrophic hypogonadism: $N$-ethyl- $N$-nitrosourea-induced gonadotropinreleasing hormone receptor gene mutation. Mol Endocrinol 2005; 19: 972-81.

78 Silveira LF, MacColl GS, Bouloux PM. Hypogonadotropic hypogonadism. Semin Reprod Med 2002; 20: 327-38.

79 Kim HG, Kurth I, Lan F, Meliciani I, Wenzel W et al. Mutations in CHD7, encoding a chromatin-remodeling protein, cause idiopathic hypogonadotropic hypogonadism and Kallmann syndrome. Am J Hum Genet 2008; 83: 511-9.

80 Jongmans MC, van Ravenswaaij-Arts CM, Pitteloud N, Ogata T, Sato N et al. CHD7 mutations in patients initially diagnosed with Kallmann syndrome-the clinical overlap with CHARGE syndrome. Clin Genet 2009; 75: 65-71.

81 Kramer PR, Wray S. Novel gene expressed in nasal region influences outgrowth of olfactory axons and migration of luteinizing hormone-releasing hormone (LHRH) neurons. Genes Dev 2000; 14: 1824-34.

82 Kramer PR, Wray S. Nasal embryonic LHRH factor (NELF) expression within the CNS and PNS of the rodent. Brain Res Gene Expr Patterns 2001; 1: 23-6.

83 Miura K, Acierno JS Jr, Seminara SB. Characterization of the human nasal embryonic LHRH factor gene, NELF, and a mutation screening among 65 patients with idiopathic hypogonadotropic hypogonadism (IHH). J Hum Genet 2004; 49: 265-8.

84 Pitteloud N, Quinton R, Pearce S, Raivio T, Acierno J et al. Digenic mutations account for variable phenotypes in idiopathic hypogonadotropic hypogonadism. J Clin Invest 2007; 117: 457-63.

$85 \mathrm{Xu} \mathrm{N}$, Kim HG, Bhagavath B, Cho SG, Lee JH et al. Nasal embryonic LHRH factor (NELF) mutations in patients with normosmic hypogonadotropic hypogonadism and Kallmann syndrome. Fertil Steril 2011; 95: 1613-20.

86 Corradi A, Croci L, Broccoli V, Zecchini S, Previtali S et al. Hypogonadotropic hypogonadism and peripheral neuropathy in Ebf2-null mice. Development 2003; 130: $401-10$.

87 Trarbach EB, Baptista MT, Garmes HM, Hackel C. Molecular analysis of $K A L-1$, GnRH-R, NELF and EBF2 genes in a series of Kallmann syndrome and normosmic hypogonadotropic hypogonadism patients. J. Endocrinol 2005; 187: 361-8.

88 Dodé C, Levilliers J, Dupont JM, de Paepe A, le Dû N et al. Loss-of-function mutations in FGFR1 cause autosomal dominant Kallmann syndrome. Nat Genet 2003; 33: 463-5.

89 de Roux N, Young J, Brailly-Tabard S, Misrahi M, Milgrom E et al. The same molecular defects of the gonadotropin-releasing hormone receptor determine a variable degree of hypogonadism in affected kindred. J Clin Endocrinol Metab 1999; 84: 567-572.

90 Massin N, Pêcheux C, Eloit C, Bensimon JL, Galey J et al. X chromosome-linked Kallmann syndrome: clinical heterogeneity in three siblings carrying an intragenic deletion of the KAL-1 gene. J Clin Endocrinol Metab 2003; 88: 2003-8.

91 Caronia LM, Martin C, Welt CK, Sykiotis GP, Quinton R et al. A genetic basis for functional hypothalamic amenorrhea. N Engl J Med 2011; 364: 215-25.

92 Cerrato F, Shagoury J, Kralickova M, Dwyer A, Falardeau J et al. Coding sequence analysis of GNRHR and GPR54 in patients with congenital and adult-onset forms of hypogonadotropic hypogonadism. Eur. J. Endocrinol 2006; 155Suppl 1: S3-10.

93 Nachtigall LB, Boepple PA, Pralong FP, Crowley WF Jr. Adult-onset idiopathic hypogonadotropic hypogonadism - a treatable form of male infertility. N Eng/ J Med 1997; 336: 410-15.

94 Raivio T, Falardeau J, Dwyer A, Quinton R, Hayes FJ et al. Reversal of idiopathic hypogonadotropic hypogonadism. N Engl J Med 2007; 357: 863-73.

Asian Journal of Andrology 